more, confidential inquiries among the distributors to the dental profession strongly suggest that these figures represent a far greater dosage of the drug than was handled by these distributors in the United Kingdom. The number of patients at risk would not appear to be as great as has been suggested. Nevertheless, on the evidence presented, the technique of intermittent methohexitone must be regarded as having serious detrimental physiological effects, which may well have been the cause of the reported deaths.

We extend our sincere gratitude to the patients who volunteered to take part in our study and indeed made it possible. Our thanks are due also to Professor J. Osborne and Professor D. S. Shovelton for making their extensive facilities available to us, and to the members of the nursing staff who assisted us so willingly. This work was supported by the Endowment Fund of the United Birmingham Hospitals.

\section{REFERENCES}

Bourne, J. G. (1967). Studies in Anaesthetics, p. 65. London, LloydLuke.
Buxton, J. D. (1967). In Intravenous Anaesthesia, edited by S. L. Drummond-Jackson, p. 16. London, Society for the Advancement of Anaesthesia in Dentistry.

Clarke, P. B. (1967). In Intravenous Anaesthesia, edited by S. L. Drummond-Jackson, p. 169. London, Society for the Advancement of Anaesthesia in Dentistry.

Drummond-Jackson, S. L. (1962). British Dental fournal, 113, 404.

Drummond-Jackson, S. L. (editor) (1967). In Intravenous Anaesthesia, p. 12. London, Society for the Advancement of Anaesthesia in Dentistry.

Dundee, J. W., and Moore, J. (1961). Anaesthesia, 16, 50.

Fishman, A. P., Fritts, H. W., and Cournand, A. (1960). Circulation, 22, 204.

Gloster, J. A., and Harris, P. (1962). Clinica Chimica Acta, 7, 206.

Huckabee, W. E. (1958). Fournal of Clinical Investigation, 37, 244.

Kurland, P. (1967). Intravenous Techniques in Dentistry, p. 11. London, Kimpton.

MacCannell, K. L. (1969). Canadian Anaesthetists' Society fournal, 16,1 .

Report of a Joint Subcommittee (1967). Dental Anaesthesia, p. 161 London, H.M.S.O.

Rowlands, D. J., Howitt, G., Logan, W. F. W. E., Clarke, A. D., and Jackson, P.'W. (1967). 'British Fournal of Anaesthetics, 39, 554.

Tomlin, P., Howarth, F. H., and Robinson, J. S. (1968). Lancet, 1, 1402.

Wyke, B. (1965). In General Anaesthesia, edited by F. T. Evans, and T. C. Gray, 2nd ed., vol. 1, p. 179. London, Butterworths.

\title{
Malabsorption of Folate Polyglutamates in Tropical Sprue
}

\author{
A. V. HOFFBRAND, * B.M., M.R.C.P. ; T. F. NECHELES, $\dagger$ M.D., PH.D. ; N. MALDONADO, $\ddagger$ M.D. \\ E. HORTA,§ M.D. ; R. SANTINI, $\|$ PH.D.
}

\begin{abstract}
Cummary : Malabsorption of folate polyglutamates pre$\checkmark$ pared from yeast has been shown in eight patients with untreated tropical sprue and in three out of six patients receiving therapy for sprue. The absorptive defect for folate polyglutamates among these 14 patients occurred more frequently and in all but one patient more severely than for folic acid.

Folate polyglutamates, the principal dietary form of folate, probably require deconjugation by the jejunal enzyme, folate conjugase, before absorption. The mean concentration of jejunal folate conjugase of 21 patients with untreated sprue and of 13 patients with sprue receiving therapy were both significantly less than the mean concentration in a control group. Nevertheless, all but five of the 34 patients had jejunal folate concentrations within the control range. There was no correlation in the individual patients between the jejunal folate conjugase concentration measured in vitro and the ability to absorb folate polyglutamates-nine patients having normal jejunal folate conjugase levels despite showing malabsorption of folate polyglutamates.
\end{abstract}

\section{Introduction}

Tropical sprue affects the structure and function of the jejunal mucosa, the principal site of folate absorption. The most likely explanation for the severe folate deficiency found in this disease

\footnotetext{
* Lecturer in Haematology, Royal Postgraduate Medical School, London W.12.

† Assistant Professor, Department of Paediatric Haematology, New England Medical Center Hospitals, Boston, Massachusetts, U.S.A

¥ Chief, Haematology Section, University Hospital, University of Puerto Rico.

$\$$ Research Assistant, Department of Haematology, University Hospital, University of Puerto Rico.

|| Pathologist, University Hospital, University of Puerto Rico.
}

is malabsorption of dietary folate. In some patients with sprue and severe folate deficiency, however, normal absorption of folic acid has been reported (Paterson et al., 1965 ; Klipstein, 1966, 1968), and such patients may show a haematological response to folic acid in physiological doses by mouth despite failing to respond to much greater amounts of ingested dietary folate (Sheehy et al., 1961). These observations suggest that patients with tropical sprue may have a much greater and more consistent defect of absorption of food folate than of folic acid itself. Food folate consists mainly of folate polyglutamates in which there are six, seven, or more glutamate moieties linked to the pteroyl portion of the molecule. Streiff and Rosenberg (1967) suggested that when these compounds are ingested in relatively pure form they are split to folate monoglutamate before entry into the blood stream by the enzyme folate conjugase present in the jejunal mucosa.

The present study was undertaken to compare directly the absorption of folate polyglutamates and of folic acid in tropical sprue and to measure the concentration of the enzyme folate conjugase in the jejunal mucosa of patients with this disease. The results show that folate polyglutamate is less well absorbed than folate monoglutamate in patients with tropical sprue but that only in a minority of the patients is this absorptive defect associated with a subnormal jejunal mucosal folate conjugase level.

\section{Subjects Studied}

Patients with Tropical Sprue.-A total of 36 patients with tropical sprue were studied, 34 from Puerto Rico and two from Haiti. The diagnosis in each was made on the basis of a clinical history of anorexia, diarrhoea, and loss of weight ; biochemical evidence of intestinal malabsorption, including an abnormal xylose excretion test, steatorrhoea, or malabsorption 
of vitamin A; a jejunal biopsy specimen showing features of tropical sprue (see below); and a bone-marrow film showing megaloblastic erythropoiesis. Folate absorption studies were performed in 14 of these patients, eight untreated and six who had received previous therapy for sprue (Table I). Jejunal mucosal folate conjugase was measured in 12 of these (in nine at the time of the absorption studies) and in the other 22 patients.

Control Subjects.-Folate absorption tests were performed on 10 normal healthy adult volunteers, including two born and living in Puerto Rico. Jejunal biopsy samples were obtained from 16 adult subjects in the U.S.A. Biopsy had been performed in these subjects for a variety of reasons, but in all cases the biopsy was of normal dissecting microscope and histological appearance, and there was no evidence of gastrointestinal disease, anaemia, or folate or vitamin- $\mathrm{B}_{12}$ deficiencies.

\section{Methods}

\section{Folate Absorption Tests}

Folate polyglutamates are not commercially available. The method of preparation used here was based on that described by Schertel et al. (1965) Fifty grammes of Difco yeast was dissolved in 1 litre of water containing $1 \mathrm{~g}$. of sodium ascorbate $\mathrm{pH} 6.2$ per $100 \mathrm{ml}$. and $0.2 \mathrm{ml}$. of 2 -mercaptoethanol per $100 \mathrm{ml}$. This solution was poured through a column of diethylaminoethanol cellulose, which was then washed with 1 litre of water containing $0.2 \%$ 2-mercaptoethanol, and the folate compounds were subsequently eluted by a gradient elution with phosphate buffer. The "free"-that is, Lactobacillus casei active-folate and folate polyglutamate content of the eluted fractions were determined by microbiological assay with and without previous treatment with folate conjugase. In addition, recovery experiments were performed in which a known amount of folate polyglutamate was added to a portion of each fraction, and the recovery of this added folate polyglutamate was determined after incubation with folate conjugase and $L$. case $i$ assay to ensure that each fraction of folate polyglutamate subsequently used was free from folate conjugase inhibitor(s) (Hoffbrand, 1969). Monkey jejunal mucosa homogenized in the proportion $1 \mathrm{~g}$. to $10 \mathrm{ml}$. of normal isotonic saline was used as the source of folate conjugase for the incubations.

The fractions containing folate polyglutamates free from inhibitor and from free folate were combined and the phosphates partly precipitated by adding $2 \frac{1}{2}$ volumes of absolute methyl alcohol and allowing the solution to stand overnight at $4^{\circ} \mathrm{C}$. The supernatant was decanted, evaporated to dryness, redissolved in a small volume of water, and passed through a column of G 10 Sephadex to separate the folate polyglutamates from remaining phosphates and 2-mercaptoethanol.

The concentration of folate polyglutamates in the final product was determined as follows. The product was diluted $1: 10,1: 20,1: 50$, and $1: 100 ; 0.5 \mathrm{ml}$. of each dilution was incubated with $1.5 \mathrm{ml}$. of the monkey small-intestinal homogenate and $8 \mathrm{ml}$. of phosphate-citrate buffer $\mathrm{pH} 4.6$ containing $1 \mathrm{~g}$. of ascorbic acid per $100 \mathrm{ml}$. and 0.01 molar calcium chloride for 90 minutes at $37^{\circ} \mathrm{C}$., autoclaved at $115^{\circ} \mathrm{C}$. for five minutes, and the free folate released assayed with $L$. casei. Folate polyglutamates prepared by this method from yeast are a complex mixture of folate compounds containing different one-carbon units-for example, methyl, formyl-attached to the folate part of the molecule, varying degrees of reduction of the folate moiety, and different numbers of glutamate moieties attached to the para-aminobenzoate portion of the molecule (Schertel et al., 1965). For the sake of convenience the concentration of folate polyglutamate is expressed here in terms of its "free folate" activity after folate conjugase digestion. For example, " $200 \mu \mathrm{g}$. folate polyglutamates" is that amount of the folate polyglutamate preparation that contains $200 \mu \mathrm{g}$. of free folic acid activity after complete digestion with folate conjugase.

Before the absorption tests were performed folate-deficient patients were first given folic acid $15 \mathrm{mg}$. daily by intramuscular injection for three days, the last dose being given at least 48 hours before the first day of the test. These injections saturated the patient with folate and ensured that failure of the serum folate to rise'after the oral dose of the vitamin could not be due to excessive clearance of absorbed folate from plasma to folate-deficient tissues.

The patient was then fasted overnight, a venous blood sample was taken, and he was given $200 \mu \mathrm{g}$. of folate polyglutamate in $50 \mathrm{ml}$. of water. An additional $50 \mathrm{ml}$. of water was given and venous blood samples were withdrawn one, two, and three hours later. On the following day the test was repeated, except that the oral dose consisted of $200 \mu \mathrm{g}$. of folic acid dissolved in $50 \mathrm{ml}$. of water and a few drops of $\mathrm{N}$ sodium hydroxide. Serum folate estimations were carried out on the venous blood samples, $L$. case $i$ being used as the test organism (Herbert, 1961). Since the folate polyglutamates used here contain many reduced and methylated forms of folate, which even as folate monoglutamates are not active for Streptococcus faecalis, measurements with this micro-organism, normally used to measure folic acid absorption (Chanarin et al., 1958), were not performed. The dose of folate polyglutamates and of folic acid used in these absorption tests was chosen to give satisfactory rises in serum folate activity in normal subjects and to be of the approximate order of daily dietary folate requirements.

\section{Estimation of Jejunal Mucosal Folate Conjugase}

Jejunal biopsy specimens after storage at $-20^{\circ} \mathrm{C}$. were homogenized in $3 \mathrm{ml}$. of cold $\left(4^{\circ} \mathrm{C}\right.$.) distilled water. Serial doubling dilutions of the homogenate were made and $0.1 \mathrm{ml}$. of each dilution, $0.1 \mathrm{ml}$. of folate polyglutamate substrate, and $1.8 \mathrm{ml}$. of phosphate-citrate buffer, $p \mathrm{H} 4 \cdot 6$, containing $1 \mathrm{~g}$. per $100 \mathrm{ml}$. of freshly added ascorbic acid and 0.01 molar calcium chloride, were incubated for 90 minutes at $37^{\circ} \mathrm{C}$. with continuous shaking. At the end of the incubation period the mixtures were autoclaved and the free folate content of the supernatant was estimated with $L$. casei. Suitable blank tubes were set up containing mucosal homogenate with no substrate and substrate with no homogenate. The protein concentration of the mucosal homogenate was measured by the method of Lowry et al. (1951) and the folate conjugase activity of the mucosa was expressed as $\mathrm{m} \mu \mathrm{g}$. of free folate released per $\mathrm{mg}$. of protein per 90 minutes (Hoffbrand and Necheles, 1968).

\section{Other Methods}

Serum folate levels were measured by the microbiological assay with $L$. casei described by Herbert (1961); the normal range is from 5 to $18 \mathrm{~m} \mu \mathrm{g} . / \mathrm{ml}$. Serum vitamin- $\mathrm{B}_{12}$ levels were estimated by the Euglena gracilis microbiological assay of Lear et al. (1954), the normal range being from 200 to 1,049 $\mu \mu \mathrm{g} . / \mathrm{ml}$. Standard haematological methods were used (Dacie and Lewis, 1963). The D-xylose excretion tests were performed with the 5-g. oral dose as reported by Santini et al. (1961); normal subjects excrete more than $1.2 \mathrm{~g}$. in the five-hour collection period. Vitamin A absorption was performed according to a modification of the method of Carr and Price (Martinez de Jesus, unpublished). A six-day faecal fat determination was performed by the method of van de Kamer et al. (1949). Normal subjects excrete less than $6 \mathrm{~g}$. of fat daily when taking a daily diet containing $100 \mathrm{~g}$. of fat.

Jejunal biopsies were classified as atrophic ; severe, moderate, mild, or non-specific jejunitis; or normal according to the criteria of Swanson and Thomassen (1965). 
TABLE I.-Clinical, Biochemical, and Haematological Findings in the 14 Patients with Tropical Sprue in whom Folate Absorption Studies were Performed

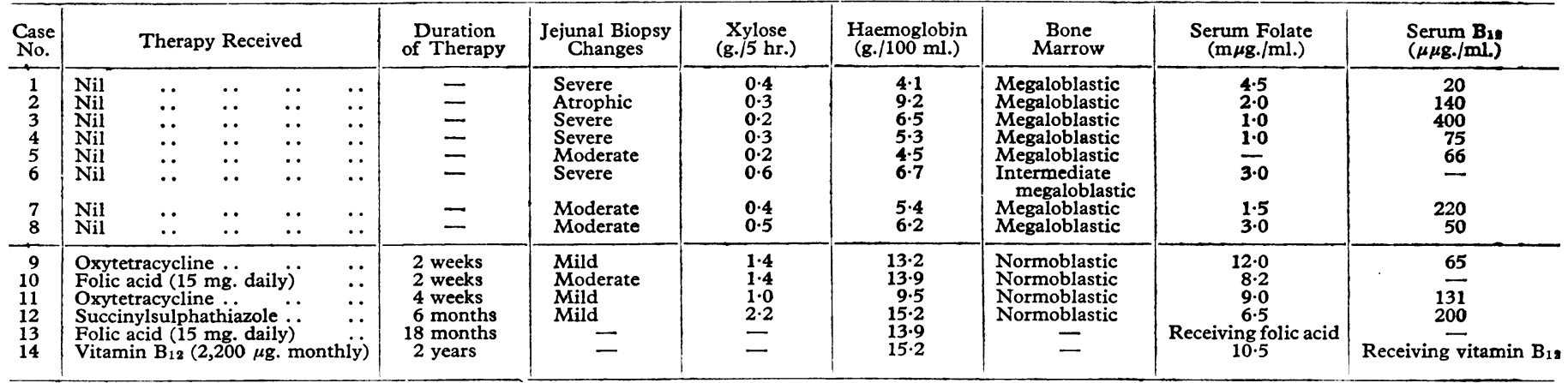

\section{Results}

The relevant clinical and laboratory findings in the 14 patients with tropical sprue in whom folate absorption tests were performed are shown in Table I.

\section{Folate Absorption Tests}

Normal subjects showed similar absolute rises in serum folate level after the oral doses of $200 \mu \mathrm{g}$. of folic acid and $200 \mu \mathrm{g}$. of folate polyglutamates (Table II) (test for paired samples, $P=0.34$ ). The lowest absolute rise in serum folate among these 10 normal subjects was $7.5 \mathrm{~m} \mu \mathrm{g} . / \mathrm{ml}$. after oral folic acid and $7.4 \mathrm{~m} \mu \mathrm{g} . / \mathrm{ml}$. after oral folate polyglutamates.

TABLE II-Results of Folate Absorption Studies in 10 Normal Subjects. Peak Rise in Serum Folate Level After the Oral Dose of Folate is Expressed Both as an Absolute Value and as a Percentage of Initial Fasting Level. Time of Peak Rise in Serum Folate After the Oral Dose is Given in Parentheses

\begin{tabular}{|c|c|c|c|c|c|c|}
\hline \multirow{3}{*}{$\begin{array}{l}\text { Sub- } \\
\text { ject } \\
\text { No. }\end{array}$} & \multicolumn{6}{|c|}{ Serum Folate } \\
\hline & \multirow{2}{*}{$\begin{array}{c}\text { Fasting } \\
\text { Level } \\
\text { (m } \mu \mathrm{g} . / \mathrm{ml} .)\end{array}$} & \multicolumn{2}{|c|}{$\begin{array}{l}\text { After } \\
200 \mu \mathrm{g} \text {. Folic Acid }\end{array}$} & \multirow{2}{*}{$\begin{array}{c}\text { Fasting } \\
\text { Level } \\
(\mathrm{m} \mu \mathrm{g} . / \mathrm{ml} .)\end{array}$} & \multicolumn{2}{|c|}{$\begin{array}{c}\text { After } 200 \mu \mathrm{g} \text {. Folate } \\
\text { Polyglutamates }\end{array}$} \\
\hline & & \begin{tabular}{|} 
Peak (Time) \\
Rise (Hours) \\
(m $\mu \mathrm{g} . / \mathrm{ml}$.)
\end{tabular} & $\begin{array}{l}\text { Peak } \\
\text { Rise } \\
(\%)\end{array}$ & & $\begin{array}{c}\text { Peak (Time) } \\
\text { Rise (Hours) } \\
\text { (m } \mu \mathrm{g} . / \mathrm{ml} .)\end{array}$ & $\begin{array}{l}\text { Peak } \\
\text { Rise } \\
(\%)\end{array}$ \\
\hline $\begin{array}{r}1 \\
2 \\
3 \\
4 \\
5 \\
6 \\
7 \\
8 \\
9 \\
10\end{array}$ & $\begin{array}{r}13.0 \\
15.5 \\
14.0 \\
13.2 \\
6.3 \\
10.0 \\
13.5 \\
7.2 \\
4.7 \\
14.5\end{array}$ & $\begin{array}{r}10.5(3) \\
22.0(2) \\
8.7(2) \\
9.6(1) \\
13.6(1) \\
10.7(2) \\
11.5(3) \\
7.5(2) \\
10.3(2) \\
14.0(1)\end{array}$ & $\begin{array}{r}81 \\
142 \\
62 \\
73 \\
213 \\
107 \\
85 \\
104 \\
70 \\
97\end{array}$ & $\begin{array}{r}10.0 \\
10.0 \\
18.5 \\
15.0 \\
8.4 \\
7.6 \\
16.0 \\
13.5 \\
15.8 \\
12.4\end{array}$ & $\begin{array}{r}12.0(2) \\
18.0(2) \\
99.5(2) \\
8.5(2) \\
12.5(3) \\
7.4(2) \\
11.7(2) \\
9.9(2) \\
11.6(1) \\
9.4(1)\end{array}$ & $\begin{array}{r}120 \\
180 \\
51 \\
57 \\
149 \\
97 \\
73 \\
73 \\
75 \\
76\end{array}$ \\
\hline ean & $11 \cdot 2$ & 11.8 & $105 \cdot 4$ & $12 \cdot 7$ & $11 \cdot 0$ & 86.6 \\
\hline
\end{tabular}

Patients with Tropical Sprue.-Four of the eight patients with untreated tropical sprue showed a subnormal rise in serum folate after oral folic acid (less than $7.5 \mathrm{~m} \mu \mathrm{g} . / \mathrm{ml}$., Table III). However, there was a greater defect in folate polyglutamate absorption among these eight patients, since all eight showed subnormal rises in serum folate after the oral dose of folate polyglutamates (less than $7.4 \mathrm{~m} \mu \mathrm{g}$. $/ \mathrm{ml}$.). In all but one of the eight patients the rise in serum folate after oral folate polyglutamate was less than that after a similar dose of oral folic acid (the difference being statistically significant, $t$ test for paired samples, $0.01>P>0.05$ ). There was also greater incidence of malabsorption of folate polyglutamate than of folic acid among the six patients receiving treatment. Thus three of these patients showed subnormal rises in serum folate after oral folate polyglutamates, whereas only one showed a subnormal rise after oral folic acid (Table III).

The absolute rise in serum folate level after an oral test dose of folate may be partly dependent on the initial fasting level. In Tables II and III, therefore, the rises in serum folate level are also expressed as a percentage of the initial fasting value.
The percentage rise in serum folate was subnormal $(<51 \%)$ after oral folate polyglutamates in six of the eight patients with untreated sprue and three of the six partly treated patients. The incidence of subnormal percentage rises in serum folate after oral folic acid $(<62 \%)$ in the sprue patients was much lower, occurring in only two of those untreated and two of those partly treated.

TABLE III.-Results of Folate Absorption Studies and of feiunal Folate Conjugase Estimations in Eight Patients with Untreated Tropical Sprue (Cases 1-8) and Six Patients with Treated or Partly Treated Tropical Sprue (Case 9-14) Whose Other Relevant Data are Gived in Table I. Time of Peak Rise in Serum Folate After the Oral Dose is Given in Parentheses

\begin{tabular}{|c|c|c|c|c|c|c|c|}
\hline \multirow{3}{*}{$\begin{array}{l}\text { Case } \\
\text { No. }\end{array}$} & \multicolumn{6}{|c|}{ Serum Folate } & \multirow{3}{*}{$\begin{array}{c}\text { Folate } \\
\text { Con- } \\
\text { jugase } \\
\text { m } \mu \mathrm{g} . \\
\text { Released/ } \\
\text { mg. } \\
\text { Protein/ } \\
90 \mathrm{~min} .\end{array}$} \\
\hline & \multirow{2}{*}{$\begin{array}{c}\text { Fasting } \\
\text { Level } \\
\text { (m m } \mu \mathrm{g} . / \\
\mathrm{ml} .)\end{array}$} & \multicolumn{2}{|c|}{$\begin{array}{c}\text { After } \\
200 \mu \mathrm{g} . \\
\text { Folic Acid }\end{array}$} & \multirow{2}{*}{$\begin{array}{c}\text { Fasting } \\
\text { Level } \\
(\mathrm{m} \mu \mathrm{g} . \\
\mathrm{ml} .)\end{array}$} & \multicolumn{2}{|c|}{$\begin{array}{l}\text { After } 200 \mu \mathrm{g} . \\
\text { Folate } \\
\text { Polyglutamates }\end{array}$} & \\
\hline & & $\begin{array}{c}\text { Peak } \\
\text { (Time) } \\
\text { Rise } \\
\text { (Hours) } \\
\text { (m } \mu \mathrm{g} . / \mathrm{ml} .) \\
\end{array}$ & $\begin{array}{l}\text { Peak } \\
\text { Rise } \\
\text { (\%) }\end{array}$ & & $\begin{array}{c}\text { Peak } \\
\text { (Time) } \\
\text { Rise } \\
\text { (Hours) } \\
\text { (m } \mathrm{mg} . / \mathrm{ml} .) \\
\end{array}$ & $\begin{array}{l}\text { Peak } \\
\text { Rise } \\
(\%)\end{array}$ & \\
\hline $\begin{array}{l}1 \\
2 \\
3 \\
4 \\
5 \\
6 \\
7 \\
8 \\
\end{array}$ & $\begin{array}{r}10 \cdot 0 \\
12.7 \\
24 \cdot 2 \\
16 \cdot 0 \\
40 \cdot 0 \\
5.0 \\
6.5 \\
3.0\end{array}$ & $\begin{array}{r}7.0(3) \\
8.0(3) \\
4.8(2) \\
20.7(2) \\
8.0(1) \\
3.3(1) \\
19.0(2) \\
4.5(3)\end{array}$ & $\begin{array}{r}70 \\
63 \\
20 \\
129 \\
20 \\
66 \\
292 \\
150\end{array}$ & $\begin{array}{r}11 \cdot 7 \\
15.0 \\
15 \cdot 0 \\
17.0 \\
40.0 \\
8 \cdot 2 \\
5.9 \\
5 \cdot 0\end{array}$ & $\begin{array}{l}3.3(2) \\
2.2(2) \\
0.5(1) \\
2.7(1) \\
1.0(3) \\
4.7(2) \\
3.9(2) \\
1.3(3)\end{array}$ & $\begin{array}{l}29 \\
15 \\
3 \\
16 \\
2 \\
57 \\
66 \\
26\end{array}$ & $\begin{array}{l}142 \\
125 \\
122 \\
= \\
325 \\
202 \\
400\end{array}$ \\
\hline Mean & $14 \cdot 7$ & $9 \cdot 4$ & 64 & $14 \cdot 7$ & $2 \cdot 4$ & 16 & 219 \\
\hline $\begin{array}{r}9 \\
10 \\
11 \\
12 \\
13 \\
14 \\
\end{array}$ & $\begin{array}{r}24.6 \\
7.5 \\
9.5 \\
13.7 \\
35.0 \\
11.2 \\
\end{array}$ & $\begin{array}{r}9.9(2) \\
14.5(2) \\
5.7(2) \\
12.5(3) \\
23.0(3) \\
9.8(2) \\
\end{array}$ & $\begin{array}{r}40 \\
193 \\
60 \\
91 \\
66 \\
88\end{array}$ & $\begin{array}{r}33.0 \\
8.2 \\
8.2 \\
20.6 \\
29.0 \\
10.5\end{array}$ & $\begin{aligned} 6.0(3) \\
7.5(2) \\
2.8(3) \\
5.6(1) \\
23.0(2) \\
12.0(1)\end{aligned}$ & $\begin{array}{r}18 \\
91 \\
34 \\
27 \\
80 \\
114\end{array}$ & $\begin{array}{l}110 \\
237 \\
328 \\
= \\
=\end{array}$ \\
\hline Mean & 16.9 & $12 \cdot 6$ & 75 & $18 \cdot 3$ & 9.5 & 52 & 225 \\
\hline
\end{tabular}

\section{Jejunal Mucosal Folate Conjugase Levels}

There was a wide variation of folate conjugase concentration in the jejunal mucosa of both the sprue patients and control subjects (see Chart). Only two untreated sprue patients and three sprue patients receiving treatment showed levels below the lower limit of the range of the normal subjects (less than $120 \mathrm{~m} \mu \mathrm{g}$. folate $/ \mathrm{mg}$. protein $/ 90 \mathrm{~min}$.). However, the mean jejunal mucosal folate conjugase concentration in the patients with untreated sprue and the sprue patients receiving treatment were both significantly less than that of the normal group $(P<0.01, P=0.02$ respectively).

\section{Discussion}

The results of this study show that patients with untreated tropical sprue have a consistent and severe defect of absorption of folate polyglutamates derived from yeast, whereas their absorption of folic acid is almost invariably less severely impaired and in some patients may be normal. These results are con- 
sistent with those reported by Jeejeebhoy et al. (1968) in patients with tropical sprue in West India. On the other hand, they are apparently at variance with the findings of Suárez et al. (1946), who described the case of a patient with untreated tropical sprue who showed a haematological response to the oral administration of folate polyglutamate. Nevertheless, the amount of oral folate polyglutamate they gave daily (equivalent to about $8.4 \mathrm{mg}$. of free folic acid) is about 100 times greater than the normal daily requirement for folic acid (50-100 $\mu \mathrm{g}$., Herbert, 1962). Thus, even if their patient had severe malabsorption of folate polyglutamates, it may well be that he could absorb as little as the $1 \%$ of the dose needed to achieve a haematological response.

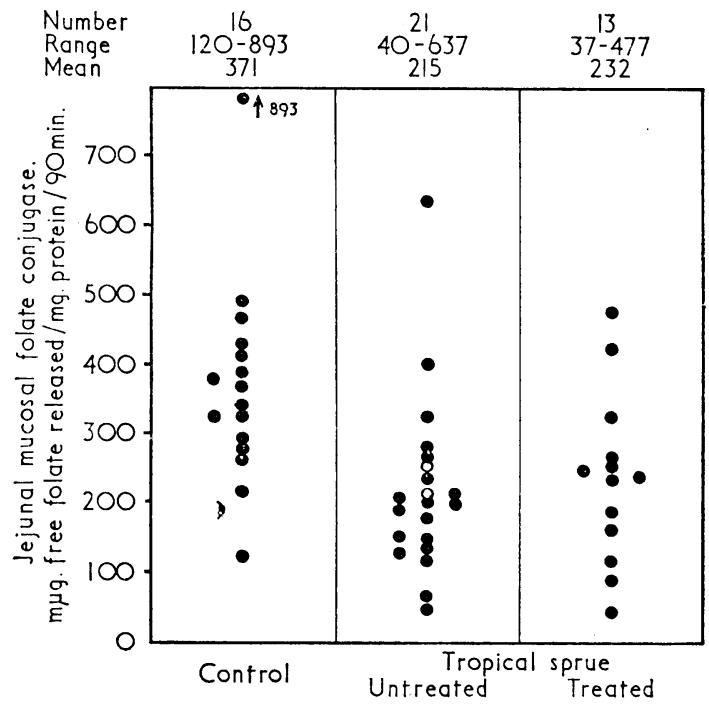

Folate conjugase concentrations in the jejunal mucosa of 16 control subjects, 21 patients with untreated tropical sprue, and 13 patients with tropical sprue receiving therapy and in partial or complete remission. The levels

in the two Haitian patients are shown (open circles).

A surprising finding here was that the mean rise in serum folate in normal subjects after the ingestion of equivalent amounts of folate as folic acid and folate polyglutamates was similar. One explanation why the yeast folate polyglutamates used here were apparently more readily absorbed than those of other workers (Spray, 1952; Perry and Chanarin, 1968) was that the compounds used here were relatively froe from conjugase inhibitor(s) reported to be present in crude yeast. Indeed, Swendseid et al. (1947) found that folate as crystalline folic acid and as pure folate polyglutamates was equally well absorbed by normal subjects and showed that the absorption of pure folate polyglutamates was significantly reduced when given with crude yeast. It would be unwise, however, to draw any firm conclusions from the present study about the comparative availability to normal subjects of ingested folate polyglutamates (whether pure or in natural foods). The form of absorption test used here-an oral tolerance test-does not measure the amount of folate absorbed. Furthermore, folic acid is cleared from the blood stream more rapidly than reduced folates (Herbert and Zalusky, 1962; Mollin et al., 1962; Chanarin and McLean, 1967). Rapid clearance therefore could reduce the rise in serum folate after oral folic acid more than after oral folate polyglutamates containing reduced and methylated forms of folate.

Absorption of folic acid did not seem to be severely impaired in some of the untreated sprue patients tested here. On the other hand, Butterworth et al. (1957) found malabsorption in all the patients with untreated tropical sprue that they tested. These workers used a larger oral test dose of folic acid than was used here, and possibly the additional stress of the larger dose made a defect in folic acid absorption more obvious. The patients of Butterworth et al. (1957) were also not saturated with folic acid before study. This technique has the advantage of not risking an improvement in intestinal function due to the folic acid therapy before study of folic acid absorption. It has the disadvantage, however, that folate-deficient tissues might take up absorbed folic acid and not release it into the plasma and urine, where it is to be measured, thus suggesting greater malabsorption of folic acid than really exists.

The explanation for the selective failure of absorption of folate polyglutamate in tropical sprue is obscure. Though there was an overall significant reduction in jejunal folate conjugase in the patients with untreated tropical sprue compared with control subjects, malabsorption of folate polyglutamates did not seem to be due to folate conjugase deficiency. Folate conjugase levels in the jejunal mucosa of many patients with untreated sprue and severe folate deficiency were within the control range reported here (see Chart). The concentrations of folate conjugase in the plasma and in the intestinal juices in tropical sprue are also normal (Santini et al., 1962, 1966; Klipstein, 1967).

Many of the sprue patients were vitamin- $\mathrm{B}_{12}$ deficient, and it has been suggested that vitamin- $\mathrm{B}_{12}$ deficiency reduces intestinal folate conjugase activity and causes malabsorption of folate polyglutamates (Bethell et al., 1947). In two patients with untreated pernicious anaemia whom we have studied, however, the rises in serum folate level following oral doses of 200 $\mu \mathrm{g}$. of folate polyglutamates were normal $(12 \mathrm{~m} \mu \mathrm{g} . / \mathrm{ml}$. and $21 \mathrm{~m} \mu \mathrm{g}$. respectively). Moreover, in the patients studied here there was no correlation between vitamin $\mathrm{B}_{12}$ deficiency and either jejunal folate conjugase level or malabsorption of folate polyglutamates. Alternative explanations for the relatively greater malabsorption of folate polyglutamates compared with folic acid in tropical sprue are that the larger folate polyglutamate molecule is less able to cross the damaged jejunal cell surface than the smaller monoglutamate molecule, or that, though the concentration of folate conjugase in the mucosa in tropical sprue when measured in vitro is normal, the enzyme may be functionally impaired in vivo.

An altogether different explanation is also possible. It could be that this defect is not so much due to an inability to deconiugate dietary folate polyglutamates in sprue but rather to their selective malabsorption compared with folic acid, because of the reduced, methylated and formylated state of the folate in them. These derivatives of folic acid may well be absorbed differently from folic acid itself, both in health and disease; for instance, owing to $p \mathrm{H}$ variations within the small intestine (Butterworth, 1968). Tests with individual folate polyglutamate compounds in pure form preferably incorporating an isotope in the folate part of the molecule are needed to decide which of these hypotheses is correct.

Whether malabsorption of dietary folate is sufficient in itself to account for the severe folate deficiency of acute tropical sprue is uncertain. It seems likely that poor dietary intake of folate aggravates the deficiency in some patients (O'Brien and England, 1964). Failure of reabsorption of folate lost into the gut lumen within jejunal and ileal mucosal cells could also be a significant contributing factor.

We wish to thank Professor M. E. Friedkin, Professor W. H Crosby, and Dr. D. M. Allen for encouragement and helpful discussions; Dr. C. Billic, of the department of gastroenterology, New England Medical Center Hospitals, for the control jejunal biopsy samples; and Miss E. J. Crawford, Mrs. H. Meyer, and Miss A. Ollen for valuable technical help. Dr. F. A. Klipstein kindly provided jejunal biopsy samples from two patients from Haiti with tropical sprue. A. V. H. was in receipt of a Medical Research Council travelling scholarship, and T.F. N. is an established investigator, American Heart Association. This work was supported in part by a suballocation from U.S. Public Health Service Institutional Grant No. R01-HE 10037 and with funds from the New England Medical Center Hospitals general research support grant from the U.S. Public Health Service No. 5-S01 FRO 05598. In 
addition, grants to N.M., E.H., and R. S. came from N.I.H. Haematology Training Grant No. 5302, Research Grant No. 02776 (Vitamin $\mathrm{B}_{12}$ Metabolism in Tropical Sprue) and No. FR 63-06 from the Division of Research Facilities and Resources, U.S. Public Health Service, Bethesda, Maryland, U.S.A.

\section{REFERENCES}

Bethell, F. H., Meyers, M. C., Andrews, G. A., Swendseid, M. E., Bird, O. D., and Brown, R. A. (1947). fournal of Laboratory and Clinical Medicine, 32, 3.

Butterworth, C. E., jun. (1968). British fournal of Haematology, 14, 339.

Butterworth, C. E., jun., Nadel, H., Perez-Santiago, E., Santini, R., jun. and Gardner, F. H. (1957). Fournal of Laboratory and Clinical Medicine, 50, 673.

Chanarin, I., Anderson, B. B., and Mollin, D. L. (1958). British fournal of Haematology, 4, 156.

Chanarin, I., and McLean, A. (1967). Clinical Science, 32, 57

Dacie, J. V., and Lewis, S. M. (1963). Practical Haematology, 3rd ed. London, Churchill

Herbert, V. (1961). Fournal of Clinical Investigation, 40, 81.

Herbert, V. (1962). Archives of Internal Medicine, 110, 649

Herbert, V., and Zalusky, R. (1962). Fournal of Clinical Investigation, 41, 1263.

Hoffbrand, A. V. (1969). British Medical fournal, 1, 51.

Hoffbrand, A. V., and Necheles, T. F. (1968). Lancet, 2, 528.

Jeejeebhoy, K. N., Desai, H. G., Borkar, A. V., Deshpande, V., and Pathare, S. M. (1968). American fournal of Clinical Nutrition, 21, 994.

Klipstein, $\mathrm{F}$. 42, 638 .

Klipstein, F. A. (1967). American fournal of Clinical Nutrition, 20, 1004.
Klipstein, F. A. (1968). Gastroenterology, 54, 275.

Lear, A. A., Harris, J. W., Castle, W. B., and Fleming, E. M. (1954). fournal of Laboratory and Clinical Medicine, 44, 715.

Lowry, O. H., Rosebrough, N. J., Farr, A. L., and Randall, R. J. (1951). fournal of Biological Chemistry, 193, 265.

Mollin, D. L., Waters, A. H., and Harriss, E. (1962). 2nd European Symposium on Vitamin $B_{12}$ and Intrinsic Factor, edited by H. C. Heinrich, p. 737. Stuttgart, Enke.

O'Brien, W., and England, N. W. J. (1964). British Medical fournal, 2,1573 .

Paterson, D. E., David, R., and Baker, S. J. (1965). British fournal of Radiology, 38, 181.

Perry, J., and Chanarin, I. (1968). British Medical fournal, 4, 546.

Santini, R., jun., Berger, F. M., Berdasco, G., Sheehy, T. W., Aviles, J., and Davila, I. (1962). Fournal of the American Dietetic Association, 41, 562 .

Santini, R., jun., Perez-Santiago, E., Walker, L., and Butterworth, C. E. (1966). American fournal of Clinical Nutrition, 19, 342.

Santini, R., jun., Sheehy, T. W., and Martinez-de Jesus, J. (1961). Gaitroenterology, 40, 772 .

Schertel, M. E., Boehne, J. W., and Libby, D. A. (1965). fournal of Biological Chemistry, 240, 3154.

Sheehy, T. W., Rubini, M. E., Perez-Santiago, E., Santini, R., jun.., and Haddock, J. (1961). Blood, 18, 623.

Spray, G. H. (1952). Clinical Science, 11, 425.

Streiff, R. R., and Rosenberg, I. H. (1967). Fournal of Clinical Investigation, 46, 1121.

Suárez, R. M., Welch, A. D., Heinle, R. W., Suárez, R. M., jun., and Nelson, E. M. (1946). Fournal of Laboratory and Clinical Medicine, 31, 1294 .

Swanson, V. L., and Thomassen, R. W. (1965). American fournal of Pathology, 46, 511 .

Swendseid, M. E., Bird, O. D., Brown, R. A., and Bethell, F. H. (1947). Fournal of Laboratory and Clinical Medicine, 32, 23.

van de Kamer, J. H., ten Bokkel Huinink, H., and Weyers, H. A. (1949). fournal of Biological Chemistry, 177, 347 .

\title{
Acidaemia and Salicylate Poisoning in Adults
}

\author{
A. T. PROUDFOOT,* B.SC., M.R.C.P.ED.; S. S. BROWN, † B.SC., PH.D.
}

British Medical fournal, 1969, 2, 547-550

\begin{abstract}
Summary : A review of the arterial acid-base status on $\checkmark$ admission to hospital of 62 adults with severe salicylate poisoning showed that arterial $p H$ was normal or high in most patients, but low in 8 . The mean plasma salicylate concentrations of the acidaemic and nonacidaemic patients were similar and the difference in arterial $p \mathbf{H}$ was associated with a marked fall in standard bicarbonate in the former group. No significant difference of $\mathrm{PCO}_{2}$ between the two groups was found, and hence no simple relationship exists between hypocapnia and the development of acidaemia in salicylate poisoning. Acidaemia is shown to be associated with impaired consciousness and to carry a grave prognosis.
\end{abstract}

\section{Introduction}

In reviewing acid-base disturbances in salicylate poisoning Smith (1966) stated that there was a "voluminous and often contradictory literature on the subject." Confusion has arisen on three points in particular. (1) Assessment of acid-base status has rarely included measurements of both respiratory and metabolic components; the results of isolated estimates of plasma $\mathrm{CO}_{2}$-combining power are apt to be misconstrued (Greer, Ward, and Corbin, 1965 ; McLaughlin, 1965).

* Senior Medical Registrar, Regional Poisoning Treatment Centre. t Senior Lecturer, University Department of Clinical Chemistry. Royal Infirmary, Edinburgh 3.
Nearly all investigators have used capillary or venous blood samples (Singer, 1954 ; Done, 1960) with attendant difficulties in the collection of specimens or the interpretation of results. (3) Generalizations about the pathogenesis of the disturbance have been made from the findings in acutely poisoned children or in adults treated with therapeutic doses of aspirin (Winters, White, Hughes, and Ordway, 1959) ; the conclusions may not be valid for poisoned adults, in whom there have been few systematic studies (Ghose, 1967 ; Posner and Plum, 1967).

While there is no doubt that acidaemia may be a feature of salicylate poisoning in young children (Tschetter, 1963; Schwartz and Landy, 1965), we are aware of only two specific reports of poisoned adults with arterial $p H$ below normal (Schreiner, Berman, Griffin, and Feys, 1955; Ghose and Joekes, 1964), each concerning only one patient. This suggests that acidaemia is a most uncommon finding in adults. Nevertheless, one patient with capillary $p \mathrm{H}$ below normal was included in the series of Ghose (1967) and a further two patients in that of Morgan and Polak (1969).

In order to determine the incidence of acidaemia, to assess its significance, and to identify the clinical features which might indicate its occurrence, we have reviewed the arterial acid-base findings in 62 severely poisoned adults.

\section{Patients and Methods}

During the three years $1966-8460$ patients over 12 years of age were admitted to the Regional Poisoning Treatment Centre, 